http://jmscr.igmpublication.org/home/ ISSN (e)-2347-176x ISSN (p) 2455-0450

crossref DOI: https://dx.doi.org/10.18535/jmscr/v9i12.36

\title{
Evaluation of the Reproductive Potentials of Azanza Garckeana Fruit Extract on Lead Treated Male Wistar Rats
}

\author{
Authors \\ Kosisochukwu. E. Didiugwu ${ }^{1}$, Chibuike Obiandu ${ }^{2 *}$, Blessing Ukoro ${ }^{1}$ \\ Henrietta.O.Asuzu-Samuel ${ }^{3}$
}

${ }^{1}$ Department of Human Physiology, Faculty of Basic Medical Sciences, College of Health Sciences, University of Port Harcourt, Choba, Rivers State, Nigeria

${ }^{2}$ Department of Human Physiology, Faculty of Basic Medical Sciences, College of Medical Sciences, Rivers State University, Nkpolu-Oroworukwo, Port Harcourt, Rivers State, Nigeria

${ }^{3}$ Department of Biomedical Technology, School of Science Laboratory Technology, University of Port

Harcourt, Choba, Rivers State, Nigeria

*Corresponding Author

Chibuike Obiandu

\begin{abstract}
Reproduction is an important biological trait to produce new individual organisms and is fundamental for the life of an individual as well as the survival and development of the species. The current study evaluated the effects of Hydro-methanolic fruit extract of Azanza garckeana on reproductive functions in male Wistar rats. Twenty (20) Wistar rats divided into 4 groups of 5 rats each were used for the study. Group 1 served as negative control and received only water and feed; group 2 received $5 \mathrm{mg} / \mathrm{kg}$ of lead acetate only, while groups 3 and 4 were administered with $200 \mathrm{mg} / \mathrm{kg}$ and $400 \mathrm{mg} / \mathrm{kg}$ of Hydro-methanolic fruit extract of Azanza garckeana respectively for a period of 28 days. At the end, the animals were anaesthesized with chlorofoam and blood was collected through cardiac puncture for hormone analysis. Semen was obtained for sperm analysis. The result showed that follicle stimulating hormone and luteinizing hormone and testosterone decreased significantly $(p<0.05)$ in the positive control (lead only) group when compared to the negative control. There was a significant increase in testosterone level in group 3 (lead $+200 \mathrm{mg} / \mathrm{kg}$ ) and group 4 (lead $+400 \mathrm{mg} / \mathrm{kg}$ ) when compared to the lead only group. The sperm parameters including viability, normal morphology, actively motile and count were decreased in the lead only group, but significantly increased in the groups that received Azanza garckeana extract. In conclusion, extracts of Azanza garckeana improved reproductive parameters in male Wistar rats with lead induced reproductive toxicity.

Keywords: Azanza garckeana, hydromethanolic, Wistar rats, reproductive functions.
\end{abstract}

\section{Introduction}

It is an established fact that over the past decades, infertility in couples has posed enormous challenge to reproductive health. Although, infertility has a global trend, the pattern in developing countries including the sub-Saharan Africa is quite disturbing. These challenges have prompted many studies by scientists from different fields of life, with the sole purpose of increasing search for fertility enhancing products, 
substances or materials particularly among the reproductive age. The outcome is encouraging as many drugs that can improve fertility, particularly in men has been produced. However, use of these orthodox medicines are accompanied with some challenges such as side effects of drugs, high cost of drugs and non-availability of drugs (Luck et al., 1995; Dietrich et al., 2003).This situation calls for improved effort into search for medicinal plants with fertility enhancing properties.

Azanza garckeana is a readily available, cheap medicinal plant with little or no adverse effects which reportedly contains specific plant pigments with anti oxidative ability such as vitamins $\mathrm{C}, \mathrm{E}$, A, carotenoids - lutein (Siddhuraju and Becker, 2003; Aslam et al., 2005). The fruits of this plant were reported in some studies to have potentials of improving fertility in female experimental Wistar rats (Dietrich et al., 2003). In males, Azanza garckeana is consumed traditionally as a remedy for poor libido but its effect on male fertility is not well documented.

Lead acetate has been shown to have some adverse effects on fertility potentials of albino Wistar rats by reducing weight and distorting the histology of some reproductive organs (Iranloye and Bolarinwa, 2009); as well as exerting toxic effects on body tissues including the testis (Pounds, 1985; Antilla, 1990; Sugiyama, 1992).

Lead has been shown to cause reproductive/ testicular toxicity by inducing oxidative stress and Azanza garckeana may influence effects of oxidative stress in tissue of rats.

The aim of this study is to evaluate the effects of Azanza garckeana on lead induced reproductive toxicity in male Wistar rats.

\section{Materials and Methods}

This study was done in the Animal House, Department of Human Physiology, Faculty of Basic Medical Sciences, University of Port Harcourt, Nigeria.

Collection and identification of plant materials Fresh fruits of Azanza garckeana were purchased from a local market in Woji community in
Obio/Akpor Local Government Area of Rivers State, Nigeria. They were identified and authenticated in the Department of Plant Science and Biotechnology, University of Port Harcourt, with the reference number: UPH/V/2,213.

\section{Extraction of plant extract}

Extraction was carried out at the department of Pharmacy and Pharmacognosy, University of Port Harcourt, Rivers State, Nigeria. The fresh fruits were rinsed thoroughly in distilled water and dried for 20 days. The dried fruits were grounded to fine powder, using a domestic electric grinder and $750 \mathrm{~g}$ of the plant material was obtained. Hydromethanol (1:4) was used as the solvent. The filtrate were pulled together and lyophilized using a freeze dryer. The yield of the hydromethanolic fruits extracts of Azanza garckeana was $18.22 \%$ (w/w). The lyophilised extract was stored air tight and kept in the dark until used.

\section{Experimental Animals}

Twenty (20) male Wistar rats were used for this study. The animals were procured from animal house, Department of Human Physiology, University of Port Harcourt, Rivers State. The animals were housed in a spacious and well ventilated cage with suitable temperature, relative humidity under 12 hour light and dark cycle. They were acclimatized for two (2) weeks and allowed access to feeds and water ad libitum.

All animals received human care according to the criteria outlined in the guide for the care and the use of Laboratory animals prepared by the National Academy of Science and published by the National Institute of Health. The ethical regulations in accordance with National and Institutional guidelines for the protection of animals' welfare were strictly adhered to during the experiments PHS (1996).

\section{Experimental Design}

A total of twenty (20) Wistar rats were used for this study, which were divided into 4 groups of 5 rats each. Group 1 served as control and received 
only water and feed. Group 2 was administered with only $5 \mathrm{mg} / \mathrm{kg}$ of lead. Groups 3 and 4 were administered with $200 \mathrm{mg} / \mathrm{kg}$ and $400 \mathrm{mg} / \mathrm{kg}$ of hydro-methanolic fruit extract of Azanza garckeana $+5 \mathrm{mg} / \mathrm{kg}$ of lead respectively.

The administrations lasted for 28 days after which the animals were sacrificed and the blood samples and semen collected for hormone assay and sperm analysis.

\section{Hormone Analysis}

The assay for testosterone and prolactin measured in $\mathrm{ng} / \mathrm{ml}$, luteinizing hormone and follicle stimulating hormone measured in $\mathrm{m} / \mu / \mathrm{ml}$ were done in accordance with established protocols and in complete observance with manufacturers' guidelines (Tietz,1986; Layman,1997)

\section{Sperm Analysis}

The epididymis was lacerated and semen was collected, emulsified with $0.5 \%$ Eosin and examined using x10 \& x 40 objective lens. Also
10-12 fields was examined to check for viable cells which is the \% of stained cells against the unstained cells. Also 10-12 field was examined to check for percentage of normal cells as against the abnormal ones. The same was done for actively motile cells. The sperm count was done using counting chamber and 1:20 dilution of the semen was done using normal saline. The chamber was assembled and filled with the diluents. The counting of the $4 \times 16$ squares was done and then multiplied by100,000.

\section{Statistical Analysis}

All statistical analysis were done using Statistical Package for Social Science (SPSS), version 20.0 software. The data were analyzed using One way Analysis of Variance (ANOVA) and Dunnett's Post hoc (multiple comparison) was used to decide the level of significance between control and test groups. The difference was considered significant at $(\mathrm{P}<0.05)$. The result was expressed in tables as mean \pm SEM.

\section{Results}

The results are presented in tables 1-4.

Table 1: Effect of extract of Azanza garckeana on FSH and LH levels

\begin{tabular}{lcccc}
\hline Groups & $\begin{array}{c}\text { FSH } \\
(\mathrm{m} / \mu / \mathrm{ml})\end{array}$ & $\begin{array}{c}\text { Relative } \\
\text { change }(\%)\end{array}$ & $\begin{array}{c}\text { LH } \\
(\mathrm{m} / \mu / \mathrm{ml})\end{array}$ & $\begin{array}{c}\text { Relative } \\
\text { change }(\%)\end{array}$ \\
\hline $\begin{array}{l}\text { Negative } \\
\text { control }\end{array}$ & $1.15 \pm 0.68$ & 0 & $1.30 \pm 1.02$ & 0 \\
Positive control $(\mathrm{Lead} 5 \mathrm{mg} / \mathrm{kg})$ & $0.19 \pm 0.15^{*}$ & -83.48 & $0.34 \pm 0.29^{*}$ & -73.85 \\
$200 \mathrm{mg} / \mathrm{kg}$ extract $+(\mathrm{Lead} 5 \mathrm{mg} / \mathrm{kg})$ & $0.41 \pm 0.28^{*}$ & -64.35 & $0.45 \pm 0.39^{*}$ & -65.38 \\
$400 \mathrm{mg} / \mathrm{kg}$ extract $+(\mathrm{Lead} 5 \mathrm{mg} / \mathrm{kg})$ & $0.28 \pm 0.23^{*}$ & -75.65 & $0.42 \pm 0.25^{*}$ & -67.69 \\
\hline
\end{tabular}

Values expressed as mean \pm SEM. $n=5$. * means values are statistically significant when compared to the negative control.

Table 2: Effect of extract of Azanza garckeana on Testosterone and Prolactin levels

\begin{tabular}{lcccc}
\hline Groups & $\begin{array}{c}\text { Testosterone } \\
(\mathrm{ng} / \mathrm{ml})\end{array}$ & $\begin{array}{c}\text { Relative } \\
\text { change }(\%)\end{array}$ & $\begin{array}{c}\text { Prolactin } \\
(\mathrm{ng} / \mathrm{ml})\end{array}$ & $\begin{array}{c}\text { Relative change } \\
(\%)\end{array}$ \\
\hline Negative control & $4.46 \pm 3.13$ & 0 & $2.72 \pm 1.72$ & 0 \\
Positive control $(\mathrm{Lead} 5 \mathrm{mg} / \mathrm{kg})$ & $1.35 \pm 0.69^{*}$ & -69.73 & $0.34 \pm 0.19^{*}$ & -87.50 \\
$200 \mathrm{mg} / \mathrm{kg}$ extract $+(\mathrm{Lead} 5 \mathrm{mg} / \mathrm{kg})$ & $1.64 \pm 0.45^{*}$ & -63.23 & $0.54 \pm 0.48^{*}$ & -80.15 \\
$400 \mathrm{mg} / \mathrm{kg}$ extract $+(\mathrm{Lead} 5 \mathrm{mg} / \mathrm{kg})$ & $2.78 \pm 2.28^{*}$ & -37.67 & $0.21 \pm 0.12^{*}$ & -92.28 \\
\hline
\end{tabular}

Values expressed as mean \pm SEM. $n=5$. */\# means values are statistically significant when compared to the negative and the positive controls respectively. 
Table 3: Effect of extract of Azanza garckeana on sperm parameters

\begin{tabular}{|c|c|c|c|c|}
\hline Groups & $\begin{array}{c}\text { Viable } \\
\text { Cells }(\%)\end{array}$ & $\begin{array}{c}\text { Normal Morphology } \\
(\%)\end{array}$ & $\begin{array}{l}\text { Actively motile cells } \\
(\%)\end{array}$ & $\begin{array}{l}\text { Sperm count } \\
\left(\mathrm{x} 10^{6} / \mathrm{ml}\right)\end{array}$ \\
\hline $\begin{array}{l}\text { Negative } \\
\text { control }\end{array}$ & $82.00 \pm 2.55$ & $78.00 \pm 2.54$ & $76.00 \pm 1.87^{\#}$ & $120.00 \pm 1.07$ \\
\hline $\begin{array}{l}\text { Positive control } \\
\text { (Lead } 5 \mathrm{mg} / \mathrm{kg})\end{array}$ & $63.00 \pm 2.55^{*}$ & $64.00 \pm 2.45^{*}$ & $54.00 \pm 4.85^{*}$ & $50.00 \pm 1.40^{*}$ \\
\hline $\begin{array}{l}200 \mathrm{mg} / \mathrm{kg} \text { extract }+ \\
(\mathrm{Lead} 5 \mathrm{mg} / \mathrm{kg})\end{array}$ & $82.00 \pm 2.00^{\#}$ & $81.00 \pm 1.00^{\#}$ & $76.00 \pm 2.45^{\#}$ & $128.00 \pm 4.90^{\#}$ \\
\hline $\begin{array}{l}400 \mathrm{mg} / \mathrm{kg} \text { extract }+ \\
(\mathrm{Lead} 5 \mathrm{mg} / \mathrm{kg})\end{array}$ & $88.00 \pm 2.00^{\#}$ & $89.00 \pm 2.45^{* \#}$ & $86.00 \pm 1.87^{\#}$ & $164.00 \pm 7.48^{* \#}$ \\
\hline
\end{tabular}

Values expressed as mean \pm SEM. $n=5$. */\# means values are statistically significant when compared to the negative and the positive controls respectively.

Table 4: Effect of extract of Azanza garckeana on weights of testes and epididymis

\begin{tabular}{|c|c|c|c|c|}
\hline Groups & $\begin{array}{c}\text { Testicular } \\
\text { weight }\end{array}$ & $\begin{array}{c}\text { Relative } \\
\text { change }(\%)\end{array}$ & $\begin{array}{c}\text { Epididymal } \\
\text { weight }\end{array}$ & $\begin{array}{c}\text { Relative } \\
\text { change }(\%)\end{array}$ \\
\hline $\begin{array}{l}\text { Negative } \\
\text { control }\end{array}$ & $1.22 \pm 0.66$ & 0 & $0.24 \pm 0.24$ & 0 \\
\hline $\begin{array}{l}\text { Positive control } \\
(\text { Lead } 5 \mathrm{mg} / \mathrm{kg})\end{array}$ & $1.10 \pm 0.55$ & -9.84 & $0.14 \pm 0.40^{*}$ & -41.67 \\
\hline $\begin{array}{l}200 \mathrm{mg} / \mathrm{kg} \text { extract }+ \\
(\mathrm{Lead} 5 \mathrm{mg} / \mathrm{kg})\end{array}$ & $1.14 \pm 0.27$ & -6.56 & $0.48 \pm 0.38^{* \#}$ & 100 \\
\hline $\begin{array}{l}400 \mathrm{mg} / \mathrm{kg} \text { extract }+ \\
(\mathrm{Lead} 5 \mathrm{mg} / \mathrm{kg})\end{array}$ & $1.40 \pm 0.71$ & 14.75 & $0.36 \pm 0.51^{\text {*\# }}$ & 50 \\
\hline
\end{tabular}

Values expressed as mean \pm SEM. $n=5$. */\# means values are statistically significant when compared to the negative and the positive controls respectively.

\section{Discussion}

This study evaluated the reproductive potentials of hydromethanolic fruit extract of Azanza gackeana on some reproductive functions in male Wistar rats administered with lead. The hormone measurements indicated that follicle stimulating hormone and luteinizing hormone were significantly decreased in the positive control group that received only lead and in those that received both extracts and lead when compared to the negative control. However, the extracts caused a non-significant increase in both hormones when compared to the lead only (positive control) group. Testosterone level was significantly reduced in the groups that received lead compared to the negative control. However, testosterone level was significantly increased in the group that received higher dose $(400 \mathrm{mg} / \mathrm{kg})$ of the extract and lead when compared to the lead only group (positive control). These results are in agreement with those reported by El-Sheikh et al., (2016), who revealed an increase in the level of serum testosterone after administration of Azanza garckeana fruit extract. The increased testosterone level acting through a negative feedback effect in the hypothalamic hypophysial gonadal axis, may have led to a non significant change in luteinizing hormone level, as a result of the interaction between luteinizing hormone and testosterone. Testosterone synthesized and produced by testicular interstitial cells is controlled via a feedback mechanism under the hypothalamicpituitary-gonadal axis control (Chang et al., 2014). Luteinizing hormone binds to its receptor in the testicular interstitial cells to promote testosterone synthesis and subsequent elevation in serum (Huang et al., 2018). The result also show that the serum prolactin level was significantly reduced in the groups that received lead compared to the negative control, however, the prolactin level was not significantly altered in the groups that received lead and extract of Azanza garckeana compared to the positive control (lead only group). Similarly, the weight of testes was 
not significantly affected in all the groups but epididymal weights were reduced significantly in the groups that received lead compared to the negative control, but the weights were significantly increased in the groups administered with lead and extract of Azanza garckeana compared to the positive control.

Evaluation of several semen parameters, including sperm count and sperm motility are essential for proper assessment of male fertility (Komiya et al., 2013). These sperm parameters may reflect any physical or chemical alterations affecting testicular tissue (Atli et al., 2016). Our result showed that all the sperm parameters analysed in this study including percentages of viable sperm cells, sperm cells with normal morphology, actively motile sperm cells and sperm count were significantly decreased in the positive control (lead only) group when compared to the negative control. However, all sperm parameters were significantly increased in the groups that received lead and extract of Azanza garckeana compared to the positive control (lead only group). Even so, some of the parameters had values exceeding the negative control value suggesting that the extract of Azanza garckeana had tremendous influence in improving sperm parameters in male rats with lead-induced reproductive toxicity. Reproductive toxicity in male rats occasioned by lead usually arise due to damaged testicular tissue structure, abnormal formation and maturation of sperms and decline in semen quality and quantity (Huang et al., 2018). Our findings which indicated a decrease in normal morphology, sperm motility and count induced by lead as well as a significant improvement in testicular functions upon concurrent administration of lead and Azanza garckeana agreed with previous report by Priyadarshani and Varma (2014), who stated that an improvement in semen parameters (count, motility, and morphology) occurred after administration of Azanza garckeana fruit extract. These observed actions of the extract may be attributed to the reportedly rich antioxidant's characteristics of Azanza garckeana, which may have influenced the epididymal antioxidant system and caused improvement in the spermatogenic process. Following administration with Azanza garckeana or isolated phytochemicals, several studies showed improved levels of detoxication biomarkers and antioxidant enzymes (Faizi et al., 1994; Ashok and Pari, 2003).

Furthermore, the ameliorative effect of Azanza garckeana extract on sperm parameters which has been attributed to its effect on the antioxidant enzyme system favors the reproductive process and also enhances spermatogenesis (D'cruz and Mathur, 2005). Metal induced toxicity is widely reported in literatures and has been attributed to oxidative stress (Pounds 1985; De-Flora and Wetherhahn 1989). Siddhuraju and Becker (2003) reported that Azanza garckeana fruit contain certain antioxidant and phenolic compounds that helps protect the testis against adverse morphologic, spermatogenic and oxidative changes brought about by toxic substances. The toxic actions of metals has been shown to be oxidative in nature (Antilla 1990 ; Leonard et al. 2004). It is noteworthy that Azanza garckeana fruit may have been able to attenuate lead toxicity due to its antioxidative potential. In a report (DeCruz, 2005), it was shown that the sperm cytoplasm contained very low concentrations of free radical sweeping enzymes. A possible increase in the antioxidant enzyme activity by Azanza garckeana fruit extract treatment favored reproductive potentials in male Wistar rats.

\section{Conclusion}

There was a decline in levels of some reproductive parameters due to lead induced toxicity in male Wistar rats. However, administration of hydromethanolic fruit extract of Azanza garckeana ameliorated the negative impact of lead on testosterone and sperm parameters including viability, morphology, motility and count in male Wistar rats. 


\section{References}

1. Antilla S (1990). "Biological effects of occupational and environmental exposure to chromium". Poirier LA, Manfait M, Etienne JC, editors. Biology and medicine. Paris: John Libbey Eurotext; p.315-9.

2. Ashok Kumar N, Pari L. (2003). Antioxidant action of Moringa oleifera Lam. (drumstick) against antitubercular drugs induced lipid peroxidation in rats. $J$. Med. $\quad$ Food. 6(3): 255- 259. https://doi.org/10.1089/109662003607166 70.

3. Aslam, M., A. Farooq, N. Raziya, R. Umer, T.G. Kazi and M. Nadeem. (2005). Mineral composition of Moringa oleifera leaves and pods from different regions of Punjab, Pakistan. Asian. J. Plant. Sci., 4: 417-421.

4. Atli, G., Canli, E.G., Eroglu, A. and Canli, M. (2016). Characterization of antioxidant system parameters in four freshwater fish species. Ecotoxicology and environmental safety 126, 30-37.

5. Chang, Y. K., Chi, L., Etnier, J.L., Wang, C.C., Chu, C.H., \& Zhou, C. (2014). Effect of acute aerobic exercise on cognitive performance: Role of cardiovascular fitness. Psychology of Sport and Exercise, 15(5), 464-470.

6. D'cruz M. (2005). Effect of piperine on the epididymis of adult male rats. Asian J. Androl., 7(4):363-8.

7. D'cruz SC and Mathur PP. (2005). Effect of piperine on the epididymis of adult male rats. Asian J. Androl. 7(4):363-8. doi: 10.1111/j.1745-7262.2005.00059.

8. De Flora S, Wetherhahn KE Mechanisms of chromium metabolism and genotoxicity. Life Chem Rep; 1989; 7:169-244.

9. Dietrich, W.E, Wilson, CJ., Montgomery, DR, McKean, J and Bauer, J. (1992). Erosion thresholds and land surface morphology, Geology, 20, 675-679, 1992.
10. Dietrich, M., Block, G., Bnowitz, N.L., Morrow, J.D., Hudes, M., Norkus, E.P and Packer, L. (2003). Ascorbic acid supplementation decreases oxidative stress biomarker f2-isoprostanes in plasma nonsmokers exposed to environmental tobacco smoke. Nutr Cancer. 45 (2): 176184.

11. El-Sheikh, El-Sayed A, Shizuo G. Kamita, Bruce D. Hammock, (2016) Effects of juvenile hormone ( $\mathrm{JH}$ ) analog insecticides on larval development and $\mathrm{JH}$ esterase activity in two spodopterans, Pesticide Biochemistry and Physiology, Volume 128

12. Faizi S, Siddiqui BS, Saleem R, Siddiqui S, Aftab K, Gilani AH. (1994). Isolation and structure elucidation of new nitrile and mustard oil glycosides from Moringa oleifera and their effect on blood pressure. J. Nat. Prod. 57(9): 1256-1261. https://doi.org/10.1021/np50111a011

13. Galal .TM. (2016). Health hazards and heavy metals accumulation by summer squash (Cucurbita pepo L.) cultivated in contaminated soils. Environ Monit Assess. 188(7):434

14. Huang, C. ; Zhang, S. ; Stein, H. H. ; Zhao, J. ; Li, D. ; Lai, C., 2018. Effect of inclusion level and adaptation duration on digestible energy and nutrient digestibility in palm kernel meal fed to growingfinishing pigs. Asian-Australas. J. Anim. Sci., 31 (3): 395-402.

15. Iranloye B. O. and Bolarinwa A. F. (2009). Effect of Nicotine administration on estrous cycle in female rats. Niger. $J$. Health and Biomed. Sci. 6: 21-25.

16. Komiya, N., Good, G. E., and Sherrod, N. B. (2013). Emotional openness as a predictor of college students' attitudes toward seeking psychological help. Journal of Counseling Psychology, 47, 138-143.

17. Layman LC, Lee EJ, Peak DB, Namnoum $\mathrm{AB}, \mathrm{Vu} \mathrm{KV}$, van Lingen BL, Gray MR, 
McDonough PG, Reindollar RH and Jameson JL. (1997). Delayed puberty and hypogonadism caused by mutations in the follicle-stimulating hormone beta-subunit gene. New England Journal of Medicine ; 337607-611.11.

18. Luck, M.R., Jeyaseelan, I. \& Scholes, R. (1995). Ascorbic acid and fertility. Biology of Reproduction. 52: 262-266.

19. Pounds JG .(1985). "The toxic effects of metals. In": Williams PL, Burson JL, editors. Industrial toxicology. New York: Van Nostrand Reinhold Co., p.197-201.

20. Priyadarshani, N. and Varma, M.C. (2014). Effect of Moringa oleifera leaf powder on sperm count, histology of testis and epididymis of hyperglycaemic mice Mus musculus. American International Journal of Research in Formal, Applied \& Natural Sciences, 7(1), June-August. 7-13.

21. Siddhuraju P, Becker K. (2003). Antioxidant properties of various solvent extracts of total phenolic constituents from three different agroclimatic origins of drumstick tree (Moringa oleifera Lam) leaves. J Agric Food Chem. 51(8): 214455.

22. Sugiyama M. (1992). "Role of physiological antioxidant in chromium (vi)-induced cellular injury". Free Radiological Biology Med;p: 397-407.

23. Tiets, N. W. (1986) Textbook of Clinical Chemistry. Saunders. 